\title{
Author Correction: Hurricane María tripled stem breaks and doubled tree mortality relative to other major storms
}

\author{
María Uriarte (1) ${ }^{1}$, Jill Thompson ${ }^{2}$ \& Jess K. Zimmerman ${ }^{3}$
}

Correction to: Nature Communications https://doi.org/10.1038/s41467-019-09319-2, published online 25 March 2019.

The original version of this Article omitted the following from the Acknowledgements:

Gabriel Arellano was instrumental in collecting post-María Hurricane data, as part of the Next Generation Ecosystem ExperimentsTropics, funded by the U.S. Department of Energy, Office of Science, Office of Biological and Environmental Research.

This has now been corrected in both the PDF and HTML versions of the Article.

Published online: 01 May 2019

\begin{abstract}
(c) Open Access This article is licensed under a Creative Commons Attribution 4.0 International License, which permits use, sharing, adaptation, distribution and reproduction in any medium or format, as long as you give appropriate credit to the original author(s) and the source, provide a link to the Creative Commons license, and indicate if changes were made. The images or other third party material in this article are included in the article's Creative Commons license, unless indicated otherwise in a credit line to the material. If material is not included in the article's Creative Commons license and your intended use is not permitted by statutory regulation or exceeds the permitted use, you will need to obtain permission directly from the copyright holder. To view a copy of this license, visit http://creativecommons.org/licenses/by/4.0/.
\end{abstract}

(C) The Author(s) 2019

\footnotetext{
${ }^{1}$ Department of Ecology Evolution and Environmental Biology, Columbia University, 1200 Amsterdam Avenue, New York, NY 10027, USA. ${ }^{2}$ Centre for Ecology \& Hydrology Bush Estate, Penicuik, Midlothian EH26 OQB, UK. ${ }^{3}$ Department of Environmental Sciences, University of Puerto Rico, San Juan, Puerto Rico 00925, USA. Correspondence and requests for materials should be addressed to M.U. (email: mu2126@columbia.edu)
} 